\title{
PENGARUH MODEL PEMBELAJARAN PENEMUAN TERBIMBING TERHADAP HASIL BELAJARSISWAPADA MATERI POKOK SUHU DAN KALOR DI KELAS X SEMESTER II SMA NEGERI 19 MEDAN T.A 2014/2015
}

\author{
Ratna Tanjung dan Indah Dewi Mentari \\ Jurusan Fisika, FMIPA Universitas Negeri Medan \\ Jl. Williem Iskandar, Psr V - Medan
}

\begin{abstract}
ABSTRAK
Penelitian ini bertujuan untuk mengetahui pengaruh model pembelajaran penemuan terbimbing terhadap hasil belajar siswa pada materi pokok Suhu dan Kalor kelas X Semester IIdi SMA Negeri 19 Medan T.A 2014/2015.Jenis penelitian ini adalahquasi experiment dengantwo group pretestposttest design. Populasi dalam penelitianadalah seluruh siswa kelas Xsemester IIyang terdiri dari 6 kelas.Pengambilan sampel dilakukan dengan cara cluster random samplingyaitu kelas X-2 sebagai kelas eksperimenyang berjumlah 31 orang dan Kelas X-5yang berjumlah 31 orang sebagai kelas Kontrol. Instrumen yang digunakanada 2 yaitu tes hasil belajar dalam bentuk essaydengan jumlah 7 soaldan lembar observasi.Uji Hipotesis menggunakan Uji t. Hasil penelitian menunjukkan: (1) model pembelajaranpenemuan terbimbingdapat meningkatkan aktivitas belajar siswa dan (2) ada perbedaanakibatpengaruh penggunaan model pembelajaran penemuan terbimbing terhadap hasil belajar siswa pada materi pokok Suhu dan Kalor di kelas X semester II
\end{abstract} SMA Negeri 19 Medan T.A2014/2015

Kata kunci:Model pembelajaran penemuan terbimbing, hasil belajar, aktivitas.

\section{ABSTRACT}

This research aimed toknow the effect of guided discovery learning model onstudents'learning outcomes in the subject mattertemperature and heatinclasS XSemester II SMA Negeri 19 Medan A.Y. 2014/2015.The type ofresearch was quasi-experimentah with two group pretest-posttest design. Thepopulation were the tenth grade students semester II cortsisting of 6 classes. Sample taking with cluster random sampling technique, the classX-2) as gxperiment class with 31 student and class X-5 with 31 student, as control class. The instrumentsused weretestof learning outcomes in the form of essay as much as7 questionsand the cobservation sheet students' learning activities. Hypothesis testwas using t test. The resultsnshowed that: (1) the guided discovery learning model can-improvestudents' learning activities and (2) there is a difference due to the effect of the use of guided discovery liearning moded to the result of student in the subject matter temperature and heat inclass XSemester HISMA Negeri 19 Medan A. Y. 2014/2015.

Keywords:Problem based learning modet, animation, learning outcome, activity.

\section{PENDAHULUAN}

Pendidikan merupakan suatu usaha sadar dan terencana untuk mewujudkan suasana belajar dan proses pembelajaran agar peserta didik secara aktif mengembangkan potensi dirinya untuk membentuk watak serta peradaban bangsa yang bermartabat agar menjadi manusia yang beriman dan bertakwa kepada Tuhan Yang Maha Esa, berakhlak mulia, berilmu, kreatif, mandiri, dan menjadi warga negara yang demokratis serta bertanggung jawab, menurut UUSPN No. 20 tahun 2003 (Abdullah, 2013 : 60). Agar tujuan pendidikan nasional dapat tercapai dengan baik dibutuhkan guru yang dapat mendidik para peserta didik. Fisika merupakan ilmu pengetahuan yang mempelajari tentang alam semesta, fenomena alam dan mekanisme yang terjadi di dalamnya.Meskipun konsep-konsep fisika erat kaitannya dengan kehidupan, hal tersebut tidak menjadi jaminan bahwa hasil belajar fisika meningkat. Banyak siswa keliru dalam memahami fisika dimana siswa sering nggapan bahwa fisika hanya penuh dengan rumus-rumus yang membuat pusing.

Melalui angket siswa yang di sebar di kelas X SMA Negeri 19 Medan diperoleh data sebagai berikut: 63,6\% siswa menyatakan bahwa pelajaran fisika itu sulit, 86,4\% siswa jarang mengulang pelajaran fisika yang telah diajarkan, 45,4\% siswa menyatakan bahwa cara guru yang mengajarkan fisika langsung menjelaskan. Berdasarkan angket, Pembelajaran fisika didominasi dengan mencatat dan mengerjakan soal saja, tidak pernah bereksperimen ataupun berdiskusi. Ketuntasan Kompetensi Minimal (KKM) di sekolah tersebut untuk mata pelajaran fisika adalah 75. Namun, sekitar 68,2\% siswa mendapat nilai rata-rata sekitar 50-70. Hasil wawancara bersama Ibu T. Simbolon sebagai guru fisika kelas X di SMA Negeri 19 Medan bahwa Ibu Simbolon mengajar fisika dengan model pembelajaran langsung, dengan metode ceramah saja. Menurut Guru fisika kelas X ini dengan ceramah siswa akan lebih mudah mengerti. 
Berdasarkan hasil wawancara dan angket yang disebar, dapat diduga bahwa penyebab rendahnya hasil belajar siswa (dibawah KKM 75) antara lain: siswa kurang tertarik belajar fisika, hal ini ditandai dengan pembelajaran fisika yang tidak pernah praktikum ataupun diskusi sehingga siswa jarang mengulang pelajaran fisika yang sudah diajarkan. Faktor lain yang menyebabkan pelajaran fisika menjadi pelajaran yang tidak disukai siswa dikarenakan gurunya yang menggunakan model pembelajaran konvensional dalam mengajar. Shadiq (2009; 9) menyatakan bahwa model pembelajaran konvensional dapat dikatakan lebih menekankan kepada para siswa untuk mengingat (memorizing) atau menghafal (rote learning) dan kurang atau tidak menekankan kepada para siswa untuk bernalar (reasoning), memecahkan masalah (problemsolving), ataupun pada pemahaman (understanding). Model pembelajaran seperti itu, kadar keaktifan siswa menjadi sangat rendah.

Pembelajaran penemuan

merupakan pembelajaran yang membuat sis dihadapkan dengan situasi di mana siswa bebas untuk mengumpulkan data, membut dugaan (hipotesis), mencoba-coba (trial and evror), mencari dan menemukan keteraturan (pola), menggeneralisasi atau menyustm rumus/beserta bentuk umum, membuktikan benan tádaknya dugaannya itu.Menurut Jerome Bromer dalam Markaban (2008 : 9) "penemuan adath suatu proses, suatu jalan/cara vdalam mondekati permasalahan bukannya suatu produk atau item pengetahuan tertentu”. Dengan demikiandiddalam pandangan Bruner, belajar dengan penemurinadalah belajar untuk menemukan, dimana seorang siswa dihadapkan dengan suatu masalah atau situasi yang tampaknya ganjil sehingga siswa dapat mencari jalan pemecahan. Pada model pembēajaran penemuan terbimbing, peran siswa cukup besar karena pembelajaran tidak lagi terpusat pada guru tetapi pada siswa. Peranan guru tidak lagi sebagai penyuplai ilmu pengetahuan. Guru lebih memerhatikan pertumbuhan dan perkembangan kognitif dan kreativitas siswa.Melalui penerapan model pembelajaran guided discovery, siswa sungguh terlibat pada persoalannya, menemukan prinsip-prinsip, dan jawaban lewat percobaan (Eko Purwanto, C., dkk., 2012).

Model Penemuan Terbimbing pernah diteliti oleh beberapa peneliti diantaranya Yanti dan Yarni Sri (2014) dimana jenis penelitiannya kuasi eksperimen di kelas X SMKN 1 Kota Bengkulu. Rata-rata hasil belajar siswa setelah diberi perlakuan model penemuan terbimbingyaitu rata-rata siswa kelas eksperimen $=80,1$ sedangkan rata-rata siswa kelas kontrol yang menggunakan model konvensional $=65,3$, peneliti memiliki kendala yaitu Kelemahan penelitian ini adalah kurang efektifnyapenggunaan waktu dan pembagian kelompok yang homogen. Penelitian selanjutnya oleh Khabibah (2014) di lakukan di SMA Negeri
Tangerang Selatan dengan sampel kelas X-3 sebagai kelas kontrol yang berjumlah 30 orang dan kelas eksperimen yaitu X-5 yang jumlahnya 30 orang. Nilai pretes rata-rata 30,7 setelah diberi perlakuan model pembelajaranpenemuan terbimbingmaka hasil belajar siswa meningkat dengan nilai rata-rata 75,9, kendala yang dialami peneliti adalah kurang menyiapkan latihan yang lebih bervariasi dankurang cermat mengalokasikan waktu. Berikutnya yaitu Nisa', Choirun dan Suliyanah (2014), penelitian dilakukan di SMP Negeri 1 Kamal dengan sampel kelas VII-A (Kelas Eksperimen) dan VII-B (kelas kontrol), hasilnya dari aspek kognitif siswa kelas eksperimen diperoleh nilai rata-rata 80,06 sedangkan kelas kontrol 61,81.Dian Yurahly,I WayanDarmadi dan Darsikin (2014), sampel penelitian diambil secara purposive sampling (pertimbangan tertentu dari guru) yaitu kelas X MIA 6 sebagai kelompok eksperimen dan kelas X MIA 2 sebagai kelompok kontrol. Tes hasil belajar fisika pada materi elaștisitas zat padat yang diperoleh menunjukkan bahwá skoỳ rata-rata kelompok eksperimen lebih tinggi 1,3 atau 6,7\% dari kelas kontrol.

Adapun tujuan penelitian adalah untuk mengetahui aktivitas belajar siswa selama diterapkan model penemuan tefbimbing pada materi pokok suhu dan kałor di kełas X semester 2 SMA Negeri 19 Medan T.A 2014/2015 dan mengetahui pengaruh 7 hasil belajar csiswa yạng diajarkan menggunakan model pembetajaran penemuan terbimbing pada materi Suhu dan Kalor. METODE RENELITIAN

Jenis Spendituian ini adalah quasi experimentdengan two group pretes-posttest design. Populasinyas seluruh siswa kelas X SMA Negeri 19

momedan tahun ajaran 2014/2015, yang terdiri dari 6 kelas. Teknik pengambilan sampel dilakukan dengan cana cluster random sampling. Sampel kelas diambil dari populasi sebanyak 2 kelas, yaitu kelas X2denganjumał 31 orang yang menggunakan model pembełajaran penemuan terbimbing dan kelas X-5 dengan jumlah 31 orangyang menggunakan pembelajarankonvensional.

Alat pengumpul data dalam penelitian ini adalah tes hasil belajar berbentuk essaydengan jumlah 7 soal yang sudah divalidasikan dan lembar observasi. Tes hasil belajar ini digunakan untuk mengetahui kemampuan siswa pada tingkat kognitif dan lembar observasi untuk mengetahui aktivitas belajar siswa.

Teknik analisis data yang digunakan dalam penelitian ini adalah analisis perbedaan dengan menggunakan rumus uji-t. Sebelum melakukan uji-t tanpa pembelajaran terlebih dahulu menghitung uji nomalitas dengan menggunkan uji Liliefors dan homogenitas varians kedua kelompok sampel dengan tes kemampuan awal. Namun sebelum menghitung uji normalitas dan homogenitas varians kedua kelompok sampel dengan tes awal, terlebih dahulu menghitung rata-rata dan standar deviasi atau simpangan baku. 
Uji hipotesis dua pihak digunakan untuk mengetahui kesamaan kemampuan awal siswa pada kedua kelompok sampel dan uji-t satu pihak digunakan untuk mengetahui apakah hasil belajar siswa dengan menerapkan model pembelajaran penemuan terbimbing lebih baik dibandingkan dengan penerapan pembelajaran konvensionalpada materi pokok suhu dan kalor.

\section{HASIL DAN PEMBAHASAN}

\section{Hasil Penelitian}

Adapun hasil penelitian ini adalah bahwa nilai rata-rata pretes kelas eksperimen sebesar 57,83 dan nilai rata-rata pretes kelas kontrol sebesar 53,69. Seperti pada tabel1 berikut :

Tabel 1.Data Nilai PretesKelas Kontrol dan Kelas Eksperimen

\begin{tabular}{llllll}
\hline \multicolumn{3}{c}{ Kelas Kontrol } & \multicolumn{2}{c}{ Kelas Eksperimen } \\
\hline No & Nilai & Frekuen & Rata- & No & Nilai Frekuen Rata-
\end{tabular}

Hasil uji normalitas diperoleh nilai postes untuk kelas eksperimen dengan harga $\mathrm{L}_{0}=0,142$ dan untuk kelas kontrol dengan harga $\mathrm{L}_{0}=0,131$ pada taraf signifikan $\alpha=0,05$ dan $\mathrm{n}=31$ diperoleh harga $\mathrm{L}_{\text {tabel }}=0,159$, maka $\mathrm{L}_{\text {hitung }}<\mathrm{L}_{\text {tabel }}$. Hasil uji homogenitas diperoleh $\mathrm{F}_{\text {hitung }}$ data postes $=1,374$ dengan $F_{\text {tabel }}$ data prostes $=1$,84.Sehingga nilai $F_{\text {hitung }}$ pada data pretes dan data postes memenuhi kriteria pengujian jikaF $F_{\text {hitung }}<\mathrm{F}_{\text {tabel, }}$, maka varians sampel homogen. Berdasarkan hasil kedua pengujian ini disimpulkan bahwa populasi berdistribusi normal dan homogen, maka telah memenuhi persyaratan untuk dilakukan pengujian hipotesis yaitu uji-t satu pihak.Adapun ringkasan perhitungan uji hipotesis data postes ditunjukkan pada tabel 4 .

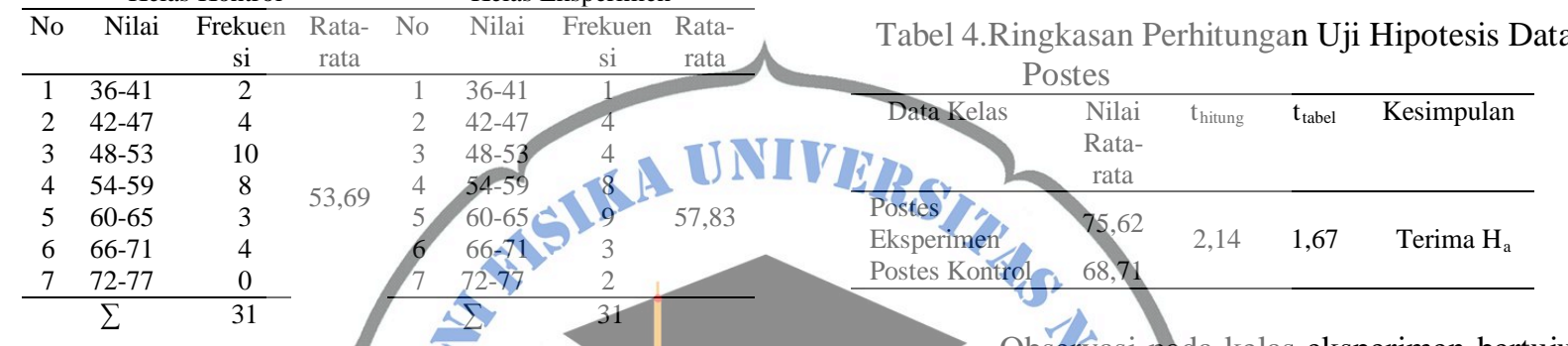

Hasil uji normalitas villai pretes untuk kelas

Observasi pada kelas eksperimen bertujuan eksperimen dengan harga $L_{0} \neq 0,100$ dan kelas kontrol $\mathrm{L}_{0}=0,086$ pada taraf signifikan $\alpha=0,05$ dan $\mathrm{n}=31$ diperoleh harga $\mathrm{L}_{\text {tabel }}=0$ 159, maka $\mathrm{L}_{\text {hitung }}<$ $\mathrm{L}_{\text {tabel. }}$.Hasil uji homogenitas dipepoleh $\mathrm{F}_{\text {hitung data }}$ pretes $=1,060$ dengan $F_{\text {tabel }}$ data pretes $=1,84$ Berdasarkan hasil kedua pengujiant phi disimpulkan bahwa populasi berdistribusi fndkmal dan homogenmaka telah memenuhi persyatatant yuntuk dilakukan pengujian hipotesis dengan hasit kij-tduam pihak seperti pada Tabel 2

Tabel 2.Ringkasan Perhitungan Uji Hipotesis Data

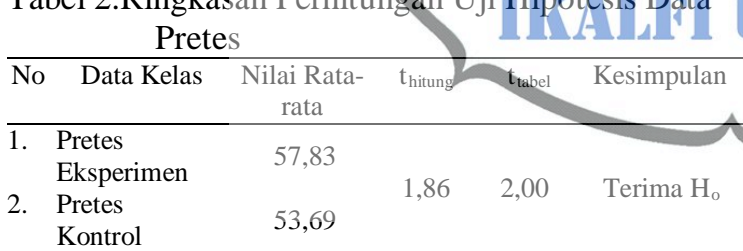

Setelah diberikan perlakuan yang berbeda, diperoleh bahwa rata-rata postes kelas eksperimen sebesar 75,62 dan rata-rata postes kelas kontrol sebesar 68,71. Adapun hasil postes kelas eksperimen dan kontrol pada materi suhu dan kalordalam bentuk tabel tertera pada tabel 3.

Tabel 3. Data Nilai PostesKelas Kontrol dan Kelas

\begin{tabular}{cccccccc}
\multicolumn{7}{c}{ Eksperimen } \\
\hline \multicolumn{7}{c}{ Kelas Kontrol } & \multicolumn{3}{c}{ Kelas Eksperimen } \\
\hline No & Nilai & $\begin{array}{c}\text { Frekuen } \\
\text { si }\end{array}$ & $\begin{array}{c}\text { Rata- } \\
\text { rata }\end{array}$ & No & Nilai & $\begin{array}{c}\text { Frekuen } \\
\text { si }\end{array}$ & $\begin{array}{c}\text { Rata- } \\
\text { rata }\end{array}$ \\
\hline 1 & $47-53$ & 6 & & 1 & $54-60$ & 4 & \\
2 & $54-60$ & 3 & & 2 & $61-67$ & 5 & \\
3 & $61-67$ & 7 & & 3 & $68-74$ & 6 & \\
4 & $68-74$ & 6 & & 4 & $75-81$ & 6 & 75,62 \\
5 & $75-81$ & 4 & 68,71 & 5 & $82-88$ & 4 & \\
6 & $82-88$ & 1 & & 6 & $89-95$ & 3 & \\
7 & $89-95$ & 4 & & 7 & $96-102$ & 3 & \\
& $\sum$ & 31 & & & $\sum$ & 31 & \\
& & & & & & & \\
\end{tabular}

untuk mengamati aktívitas belajar siswa selama pembetajaran dengan model penemuan terbimbing. Observasi dilakukan selama kegiatan belajar mengajar yang terdiri dari empat kali pertenuan. Perkembangan aktivitas siswa di kelas eksperimen mengalami peningkatan selama menerina pembelajaranseperti yang ditunjukkan চada gaimbar 1 berikut. 
aktif.Adapuan nilai Akivitas jika dibandingkan dengan data nilai hasil belajar siswa berupa nilai LKS dapat dilihat pada tabel 5 berikut ini.

Tabel 5.Data Aktifitas Belajar dengan Data Hasil Belajar (Nilai LKS)

\begin{tabular}{|c|c|c|c|c|c|}
\hline No & Pertemu-an & $\begin{array}{c}\text { Rata-Rata Nilai } \\
\text { Aktivitas (\%) }\end{array}$ & Kriteria & $\begin{array}{l}\text { Rata-Rata } \\
\text { Nilai LKS }\end{array}$ & Kriteria \\
\hline 1. & Pertama & 59,1 & $\begin{array}{l}\text { Cukup } \\
\text { Aktif }\end{array}$ & 72,9 & $\begin{array}{l}\text { Cukup } \\
\text { Baik }\end{array}$ \\
\hline 2. & Kedua & 69,2 & Aktif & 79,8 & Baik \\
\hline 3. & Ketiga & 75,6 & Aktif & 84,7 & $\begin{array}{l}\text { Sangat } \\
\text { Baik }\end{array}$ \\
\hline 4. & Keempat & 82,3 & $\begin{array}{l}\text { Sangat } \\
\text { Aktif }\end{array}$ & 87,9 & $\begin{array}{l}\text { Sangat } \\
\text { Baik }\end{array}$ \\
\hline
\end{tabular}

\section{Pembahasan}

Hasil belajar siswa dengan menggunakan model penemuan terbimbing pada materi suhu dan kalor sebelum diberikan perlakuan nilai rata-rata pretes sebesar 57,83 dan setelah diberikan perlakuan nilai rata-rata postes siswa sebesar 75,62, sedangkan hasil belajar siswa dengan menggunakanpembelajarankonvensional pada materi suhu dan kalor sebelum diberikan perlakuan nilai rata-rata pretes sebesar 53,69 dar setelah diberikan perlakuan nilai rata-rata postes siswa sebesar 75,62. Data ini menunjukkian perbedaan hasil belajar yang didapat oleh setiap kelas.

Berdasarkan tabel 1, Nilai pretes kelas eksperimen berbeda dengan nilai pretes kelas kontrol. Nilai rata-rata yang didapat kelas eksperimen sebesar57,47dan nilai raka-rata kelas kontrol sebesar 53,73. Untuk melihat perbedaan kemampuan awal kedua kelas dilakekan uji hipotesis dengan uji prasyarat ýaitu uji normalitas dengan menggunakan uji lilliefors tan homegenitas dengan menggunakan uji-F didapat bahwa poptiasi berdistribusi normal ( $\mathrm{L}_{\text {hitung }}<\mathrm{L}_{\text {tabel }}$ ) dan homogen $\left(\mathrm{F}_{\text {hitung }}<\mathrm{F}_{\text {tabel }}\right)$, sehingga dilakukan uji-hipotesis yaitu uji-t dua pihak pada kedua nilai pretes, dan. diperoleh hipotesis nol $\left(H_{0}\right)$ diterima. Hat ini terlihat dalam tabel 2 dimana $t_{\text {hitung }}<t_{\text {tabel }}(1,86<2,00)$. Hal ini menunjukkan kemampuan awal kedua kelas sama, karena kedua kelas memiliki kemampuan awal yang sama maka peneliti dapat melanjutkan penelitian dengan memberikan perlakuan yang berbeda pada kedua kelas. Kelas eksperimen diberikan perlakuan menggunakan model penemuan terbimbing sedangkan kelas kontrol diberikan perlakuan menggunakan pembelajaran konvensional.

Hasil belajaryang didapat setelah diberikan perlakuan (postes) pada kedua kelas yang terdapat pada tabel 3. Nilai rata-rata yang didapat kelas eksperimen sebesar 75,62 berbeda dengan nilai ratarata kelas kontrol sebesar 68,71. Untuk melihat perbedaan hasil belajar siswa akibat pengaruh model penemuan terbimbingdilakukan uji hipotesis dengan uji prasyarat yaitu uji normalitas dan homogenitas didapat bahwa populasi berdistribusi normal dan homogen, dengan kriteria pengujian normalitasyaitu: $\mathrm{L}_{\text {hitung }}<\mathrm{L}_{\text {tabel }}$ dan kriteria pengujian homogenitas yaitu: $F_{\text {hitung }}<F_{\text {tabel }}$. Sehingga dilakukan uji hipotesis yaitu uji-t satu pihak pada kedua nilai postes, dan diperoleh bahwa kemampuan kedua kelas adalah berbeda. Hal ini terlihat dalam tabel 4 , dimana $t_{\text {hitung }}$ $>t_{\text {tabel }}(2,14>1,67)$. Hal ini menunjukkan bahwa hipotesis alternatif $\left(H_{a}\right)$ diterimayaitu ada perbedaan hasil belajar siswa akibat pengaruh model penemuan terbimbing pada materi suhu dan kalor di SMA N 19Medan bila dibandingkan dengan pembelajaran konvensional.Hasil yang diperoleh pada penelitian ini sejalan dengan penelitian yang dilakukan sebelumnya oleh Sumarniti, Ni Nym., dkk. (2014) hasil belajar, kelompok eksperimen memperoleh skor rata-rata hasil belajar IPA lebih tinggi dibandingkan skor rata-rata hasil belajar IPA pada kelompok kontrol. Skor rata-rata hasil belajar IPA kelompok eksperimen adalah 14,85 dan skor rata-rata hasil belajar IPA kelompok kontrol adalah $12(14,85>12)$.

Besarnya peningkatan hasil belajar di kelas éksp̄enimen pada saat proses belajar karena model penemuan terbimbing menuntut cara belajar siswa aktif dengan ménemukan sendiri dengan dibimbing maka hasil yang diperoleh tidak mudah dilupakan siswa. Model penemuan terbimbing memberikan kesempatan kepada sîswa untuk menemukan kosepkonsep fisik@? Siswa đalam hal ini aktif dan antusias untuk bekeryasama dengan teman satu kelompok dalam menemokan dan menyelidiki konsep-konsep fisika yang terah diberikan oleh peneliti. Pembelajaran model penemuan terbimbingmembantu siswa membentuk cara kerja bersama yang efektif, saling membagi informasi, serta nnemdengar dan-menggunakan ide-ide orang lain. Siswajjuga teitarik aktif saat berdiskusi saat modakan diskusi antar kelompok. Konsep-konsep fisika yang dipelajari dihubungkan dalam kehidupan sehari-hari ssehingga siswa tertarik untuk mempelajarinya.

Selain pengaruh terhadap hasil belajar siswa model pembelajaran penemuan terbimbingmemberikan kontribusi terhadap aktivitas belajar siswa yang diamati oleh observer. Hal ini dapat dilihat pada gambar 1. Dari gambar dapat dilihat bahwa rata-rata peningkatan aktivitas belajar siswa di kelas eksperimen mengalami peningkatan selama menerapkan model pembelajaran penemuan terbimbing yaitu pada pertemuan I menunjukkan siswa cukup aktif dengan nilai rata-rata aktivitas belajar adalah 59,1\%. Pertemuan II siswa mulai aktif walaupun ada beberapa siswa yang masih cukup aktif dimana rata-rata aktivitas belajar sebesar $69,2 \%$. Pertemuan III dengan rata-rata sebesar 75,6\% siswa terlihat aktif secara menyeluruh, dan pertemuan IVdiperoleh rata-rata aktivitas yaitu 82,3\% dengan kriteria sangat aktif.Sehingga dengan diperoleh peningkatan aktivitas belajar siswa dari pertemuan I sampai IV dengan rata-rata nilai seluruhnya adalah $71,46 \%$ dengan kriteria penilaian aktif.

Nilai aktivitas dari pertemuan ke-I sampai 
ke-IV mengalami peningkatan, hal ini sebanding dengan nilai hasil belajar melalui LKS siswa. Hal ini dapat kita lihat pada tabel 5, Berdasarkan tabel 5, dapat dilihat bahwa rata-rata nilai LKS siswa pada pertemuan I sebesar 72,9, hal ini disebabkan belum terbiasa siswa dengan model penemuan terbimbing sehingga terlihat canggung dalam belajar dimana banyak yang tidak mendengarkan arahan dari peneliti dan tidak menulis data percobaan dan aktivitas siswa terlihat cukup aktif. Pada pertemuan ke-II diperoleh nilai LKS sebesar 79,8, hal ini terlihat juga pada aktivitas dimana siswa belum seluruhnya aktif, masih ada yang ragu-ragu dalam mengeluarkan pendapat, dalam diskusi dan siswa menjawab LKS tidak lengkap. Pada pertemuan ke III rata-rata nilai LKS sebesar 84,7. Hal ini karena siswa sudah memahami tugas mereka dan siswa terlihat aktif ketika berdiskusi, mau bertanya dan menjawab ketika diberikan pertanyaan. Pada pertemuan ke-IV nilai rata-ratanya yaitu 87,4 dan siswa terlihat sangat aktif, hal ini karena siswa merasa tertantang untuk menemukan dar antusias dalam melakukan percobaan sesuaidengan prosedur LKS serta jawaban LKS siswa baik dan lengkap sehingga ada beberapa siswa yang mencapai nilai maksimal. Adapun rata-rata nilai LKS dari pertemuan ke-I sampai ke-Iy adalały 81,33 dengan kriteria penilaian baik.

Pada saat model penemman terbimbing diterapkan dikelas eksperimen, peneliti menemukan beberapa kelebihan dan kekwangan. Adapun kelebihan dari model ini antara tain:menyebabkan peserta didik aktif dengan kegiatan belajarnya sendiri dengan melibatkan akathya dalam menemukan dan Kellakukan eksperimen;menimbulkan rasa senang pada peserpan didik, karena tumbuhnya rasa menyelidiki dan berhasil; menimbulkan rasa puas bagi sìswa. Kepuasan batin ini mendorong ingin melakukan penemuan lagi sehingga minat belajarnya meningkat.

Adapun kendala yang dihadapi peneliti yaitu kurangnya kesiapan siswa ketika menjawab pertanyaan-pertanyaan yang peneliti berikan. Hal ini disebabkan karena sebelum memulai pembelajaran siswa tidak mempelajari materi terlebih dahulu. Selain itu,dalam pembagian kelompok peneliti memberikan siswa kebebasan untuk memilih sendiri kelompoknya sehingga menimbulkan keributan dan kelompok yang terbentuk cenderung homogen.

Kesulitan berikutnya adalah masih kurangnya pengetahuan awal siswa tentang alat alat praktikum. Sehingga peneliti harus menjelaskan terlebih dahulu fungsi dan cara penggunaan alat-alat yang ada saat praktikum. Ini tentunya memakan waktu yang cukup banyak, sehingga waktu praktikum menjadi sedikit terganggu. Untuk mengatasi hal ini, sebaiknya sebelum menerapkan model pembelajaran penemuan terbimbing dalam materi suhu dan kalor, siswa terlebih dahulu diajarkan mengenal alat-alat praktikum suhu dan kalor dengan benar sehingga ketika praktikum dilakukan siswa sudah dapat mengetahui fungsi alatalat tersebut dan waktu dapat digunakan secara efektif.Dari pembahasan diatas dapat diambil kesimpulan bahwa ada perbedaan hasil belajar siswa akibat pengaruh model penemuan terbimbing terhadap hasil belajar siswa pada materi pokok suhu dan kalor di kelas X SMA N 19 Medan T.A. $2014 / 2015$.

\section{KESIMPULAN DAN SARAN}

Dari hasil analisis yang dilakukan dalam penelitian ini diperoleh kesimpulan sebagai berikutDari hasil ini tampak bahwa nilai postes kelas eksperimen lebih tinggi dibandingkan dengan kelas kontrol dengan perbedaan peningkatan sebesar 6,91 sehingga dapat dikatakan bahwa model pembelajaran penemuan terbimbing memberikan pengaruh yang signifikan terhadap hasil belajar siswa pada materi pokok suhu dan kalor di kelas X semester II SMA Negeri 19 Medan. Dari hasil observasi didapatkan bahwa penerapan model pembelajaran penemuan terimbingdapat meningkatkan aktivitas belajar siswa yaitu rata-rata nilainya adalah 71,46\% dengan kategori aktif.

Saran untuk peneliti selanjutnya sebaiknya sebelim menerapkan model pembelajaran penemuan terbinging dalam materi suhu dan kalor, siswa terlebihndahulu diajarkan mengenal alat dan bahan praktikum gengan benar sehingga ketika siswa melakukam zeksperimen tidak bingung dan sudah mengetahui fungsi alat dan bahan tersebut sehingga wakta dapat-digunakan secara efektif dan ditiarapkan lebih mengoptimalkan pengelolaan kelas knususnya pada saat diskusi berlangsung agar kelas kondusif.

\section{J N DAFTAR PUSTAKA}

Abdullah. 2013. Sosiologi Pendidikan (Individu, Masyarakat, dan Pendidikan). Jakarta : PT Raja Grafindo Persada.

Eko Purwanto, C., dkk. 2012. Jurnal Pendidikan Fisika Universitas Negeri Semarang(Penerapan Model Pembelajaran Guided Discovery Pada Materi Pemantulan Cahaya Untuk Meningkatkan Berpikir Kritis). Vol. 1 No. 1.

Khabibah, Rina. 2014. Pengaruh Model Guide Discovery Learning Terhadap Hasil Belajar Siswa SMA pada Konsep Gerak Melingkar Beraturan. Jakarta: Universitas Islam Negeri Syarif Hidayatullah

Nisa', Choirun dan Suliyanah. 2014. Jurnal Inovasi Pendidikan Fisika Universitas Negeri Surabaya (Pengaruh Penerapan Pembelajaran Penemuan TerbimbingdenganMengintegrasikan Keterampilan Proses Sains terhadap Hasil Belajar Siswa SMP Negeri 1 Kamal).Vol3. No. 1. 
Shadiq, Fadjar. 2009. Model-Model Pembelajaran Matematika SMP. Pusat Pengembangan dan Pemberdayaan Pendidik danTenaga Kependidikan (PPPPTK) Matematika : Departemen Pendidikan Nasional.

Sumarniti, Ni Nym., dkk. 2014. Jurnal Mimbar PDSG Universitas Pendidikan Ganesha(Pengaruh Model Guided Discovery Learning Terhadap Hasil Belajar Ipa Pada Siswakelas V Di Sd Gugus Vii Kecamatan Sawan Tahun Pelajaran 2013/2014). Vol. 2 No.1

Yanti, Yarni Sri. 2014 PengaruhPenerapanModelpembelajaranPenemu anTerbimbing(Guided Discovery)Terhadap Hasil Belajar Fisika di SMKN 1Kota Bengkulu. Bengkulu : Universitas Bengkulu.

Yurahly, Dian, dkk. 2014. Jurnal Pendidikan Fisika
Universitas Tadulako (Model Pembelajaran Guided Discovery dan Direct Instruction Berbasis Keterampilan Proses Sains Siswa SMA Negeri 4 Palu). Vol. 2 No. 2.

Markaban.2008. Model Penemuan Jerbimbing pada Pembelajaran Matematika SNMK Pusat Pengembangan Dan Pemberdayaan Pendidik DanTenaga Kependidikan N(PPPPTK) Matematika : Departemen Pendidikan Hasional.

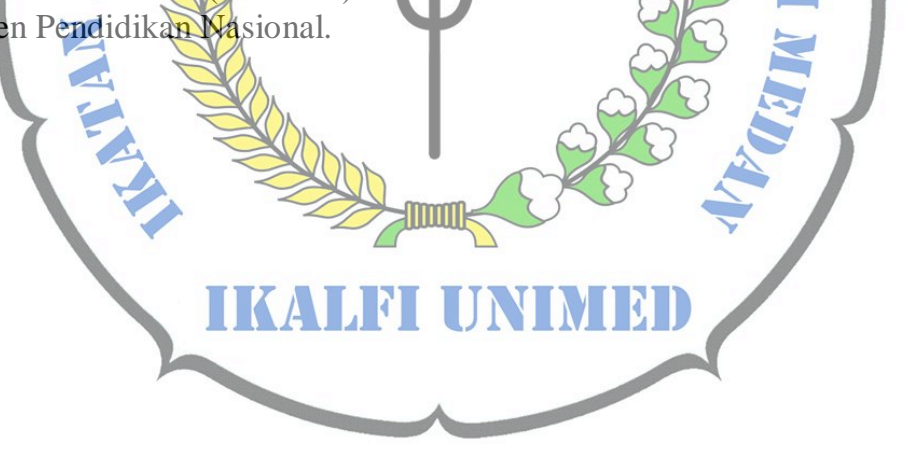

